\title{
Disseminated neoplasia in juvenile eastern oysters Crassostrea virginica, and its relationship to the reproductive cycle
}

\author{
Susan E. Ford*, Robert D. Barber, Elizabeth Marks \\ Rutgers University, Institute of Marine and Coastal Sciences and New Jersey Agricultural Experiment Station, Haskin Shellfish Research \\ Laboratory, 6959 Miller Avenue, Port Norris, New Jersey 08349, USA
}

\begin{abstract}
An unusually high incidence of disseminated neoplasia was found in a single year class of juvenile oysters surveyed histologically in lower Delaware Bay, New Jersey, USA. Neoplasms were found on 13 of the 18 collection dates, and in 19 of the 834 oysters sampled, between 23 April and 24 October 1991. No cases were found among the more than 2200 other juvenile oysters examined from 1988 to 1994 . The prevalence pattern of neoplasia followed that of gametogenesis, suggesting some link with the reproductive process, although oysters with neoplasia generally had lower gonadal indices than those without the disorder. The occurrence of neoplasia in this group of oysters was associated with exceptionally heavy setting of that year class. The resulting extreme crowding may have stressed the oysters and would have fostered transmission of a putative infectious agent.
\end{abstract}

KEY WORDS: Neoplasia - Oyster - Crassostrea virginaca Gametogenesis

Neoplasms in molluscs were first described in the eastern oyster Crassostrea virginica (Couch 1969, Farley 1969), but there have been relatively few additional published accounts for this species (see Newman 1972, Frierman 1976, Couch \& Winstead 1977, Couch 1985). Most information on molluscan neoplastic diseases comes from mussels Mytilus edulis and clams Mya arenaria, which often exhibit very high prevalence (Elston et al. 1992). Of 8 histopathological surveys in which neoplasms of eastern oysters have been reported (Peters 1988, Elston et al. 1992), only one found greater than $0.5 \%$ prevalence and most found considerably less than $0.1 \%$. In this report, we describe an episode of disseminated neoplasia in young eastern oysters, which resulted in unusually high prevalence and which appeared to be associated with the reproductive cycle. Frequent sampling allowed us to describe short-term disease patterns more precisely than in most other studies.

\footnotetext{
•E-mail:susan@hsrl.rutgers.edu
}

Frierman (1976) reported epizootic neoplasia (31 of 369 individuals; $8.4 \%$ ) in 2 inbred strains of juvenile eastern oysters from Chesapeake Bay, Virginia, USA. He contrasted this with a much lower prevalence among other inbred and wild oysters from the same area that were examined histologically between 1964 and 1976 (39 of 51000 individuals; $0.076 \%$ ). The Haskin Shellfish Research Laboratory has a similarly long history of examining eastern oysters for diseases (1958 to 1995) and finding only very occasional neoplastic disease $(<0.01 \%)$ in Delaware Bay, New Jersey, USA

Materials and methods. In 1988, we began an intensive survey of juvenile Crassostrea virginica in Delaware Bay to document the prevalence of spores of the protozoan Haplosporidium nelsoni (cause of MSX disease) in young oysters (Barber et al. 1991). From 1988 to 1994,3000 oysters between 1 and 15 mo old were collected for histological examination. Before and after 1991, none of these individuals was diagnosed with neoplasia. In 1991, however, we found unusually high prevalences of the disorder in the 1990 year class that had set on the intertidal flats in front of the Rutgers Cape Shore Laboratory in lower Delaware Bay.

Between 23 April and 24 October 1991, 18 collections were made. Fourteen of these, from 3 June through 19 September, were weekly. At each sampling, 25 to 78 juvenile oysters (total $N=834$ ) were examined by tissue-section histology for parasites and pathological conditions. We used image analysis to examine the relationship of neoplasia to the reproductive cycle which occurred during the study period. The cross-sectional areas of the visceral mass and the gonad were measured in 19 to 20 oysters from each sample, including all neoplastic individuals (total $N=330$ ). A gonadal index was calculated as the proportion of visceral mass area occupied by the gonad (Barber et al. 1988). 
Results and discussion. Disseminated neoplasms were found on 13 of the 18 collection dates, and in 19 of the 834 oysters $(2.3 \%)$ (Fig. 1). The appearance of neoplastic cells was the same in all affected oysters and matched that described by others (Farley 1969, Frierman 1976). The cells had enlarged nuclei, frequent mitotic figures, and scant cytoplasm (Fig. 2A). Fourteen of the 19 cases were heavy, with neoplastic cells abundant in all vascular spaces, especially those of the gill (Fig. 2B, C, D). Three cases were light, with neoplastic cells scattered in all vascular spaces, but concentrated in the gonad. Oysters with moderate to heavy neoplasia were present during most of the study period. Two individuals with very light neoplasia were found in early August at the beginning of the second neoplasia peak (Fig. 1). In one, the neoplastic cells were concentrated in a few gonadal follicles and adjacent connective tissue of a sexually undifferentiated oyster. In the second, neoplastic cells were obvious only in a few scattered pockets in the gill. Despite the abundance of neoplastic cells in the vascular system, epithelia and connective-storage cells appeared morphologically normal (Fig. 2B, C, D).

Gonadal development occurred rapidly between mid May and early June (Figs. 1 \& 3). Some oysters apparently spawned in late June, as indicated by a slight decrease in gonadal index, but the major spawning began in mid July. A few oysters ( 1 to 4 per sample) with ripe gonads were found in September and October, but the average sample gonadal index was $<5 \%$. The neoplasia prevalence pattern during the reproductive period was distinctly bimodal with a peak of $5 \%$ in late June and a second peak of about $2.5 \%$ extending from early August through September (Fig. 1). The first

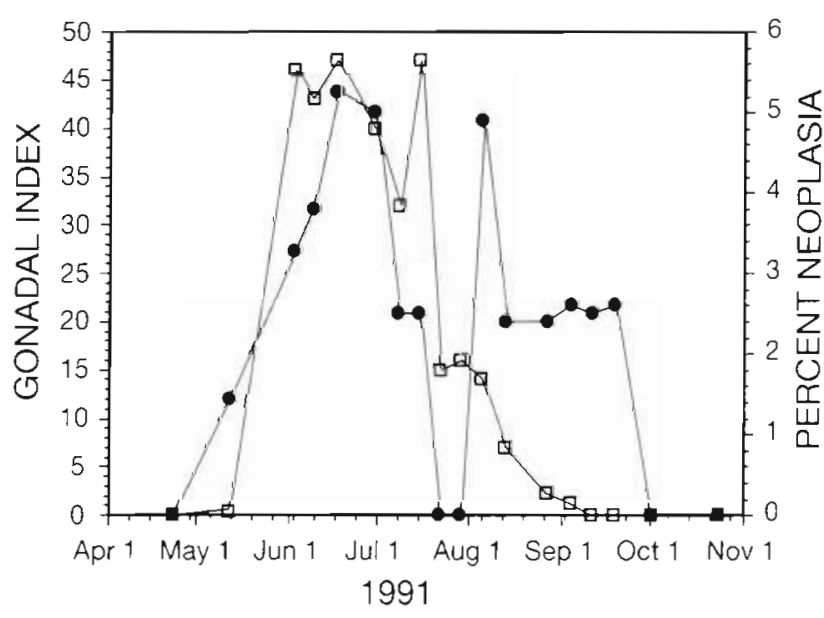

Fig. 1. Seasonal gonadal indıces ( $\square$ ) and prevalence of neoplasia (•) in 1990 year-class oysters collected from lower Delaware Bay, New Jersey, USA, intertidal flats in 1991. $N=19$ to 20 for each gonadal index sample and 25 to 78 for each neoplasia sample neoplasia peak co-occurred with the period of maximum gonadal development and began to decline with the first sign of spawning, in early July. The second neoplasia peak occurred after the major spawning During the latter period, neoplasms occurred only in oysters without measurable gonads. No neoplasia was found in the 23 April or the 1 and 24 October samples, i.e. before and after the reproductive period. There was also an interval in late July, which coincided with spawning, during which no neoplasms were found. Two of the 19 oysters with neoplasia were infected with Haplosporidian nelsoni, but chi-squared analysis showed that this proportion was statistically the same $(p=0.304)$ as that for oysters without neoplasia

Although clearly distinct from the gonadal neoplasms described in hard clams Mercenaria spp. (Hesselman et al. 1988), disseminated neoplasms have 2 hypothesized associations with reproduction (Elston et al. 1992): (1) a gonadal origin and (2) an inhibitory effect on gametogenesis. Farley (1969) first suggested an origin for neoplastic cells in the 'primordial epithelium of the gonad' after noting the morphological resemblance among undifferentiated germ cells, normal hyaline hemocytes, and neoplastic cells in eastern oysters. Rasmussen (1986) later pointed out the similarity between focal development of both germinal and neoplastic cells in vesicular connective tissue of Mytilus edulis and also suggested a gonadal origin for the latter. We were unable to identify an origin for the neoplastic cells from tissue slide examination; however, the striking temporal correlation betwcen the prevalence of neoplasms and degree of gametogenic activity in our study may offer some support for the gonadal origin hypothesis. Alternatively, the exceptional metabolic changes associated with seasonal reproduction in bivalves (Gabbott 1975) could trigger abnormal cellular development, regardless of the tissue of origin.

Although neoplasia appears to be lethal for some molluscs, reports of its effect on gametogenesis are equivocal, ranging from arrested development to no apparent consequence (Farley 1969, Cosson-Mannevy et al. 1984.). Elston et al. (1992) found neoplasia associated with retarded gametogenesis in Mytilus edulis during periods of low ambient food supply, but not during times of abundant food. This suggested that energy allocation favored neoplastic cells over gametes at times when food was limiting. In our study, most of the oysters with neoplasia had measurable gonads, but their gonadal indices were generally below the mean for non-neoplastic individuals (Fig. 3). Phytoplankton. is typically abundant at the collection site (Ford 1986) and supports excellent oyster growth, although natural setting is often heavy and may result in very localized food depletion in dense clusters of young oysters. 


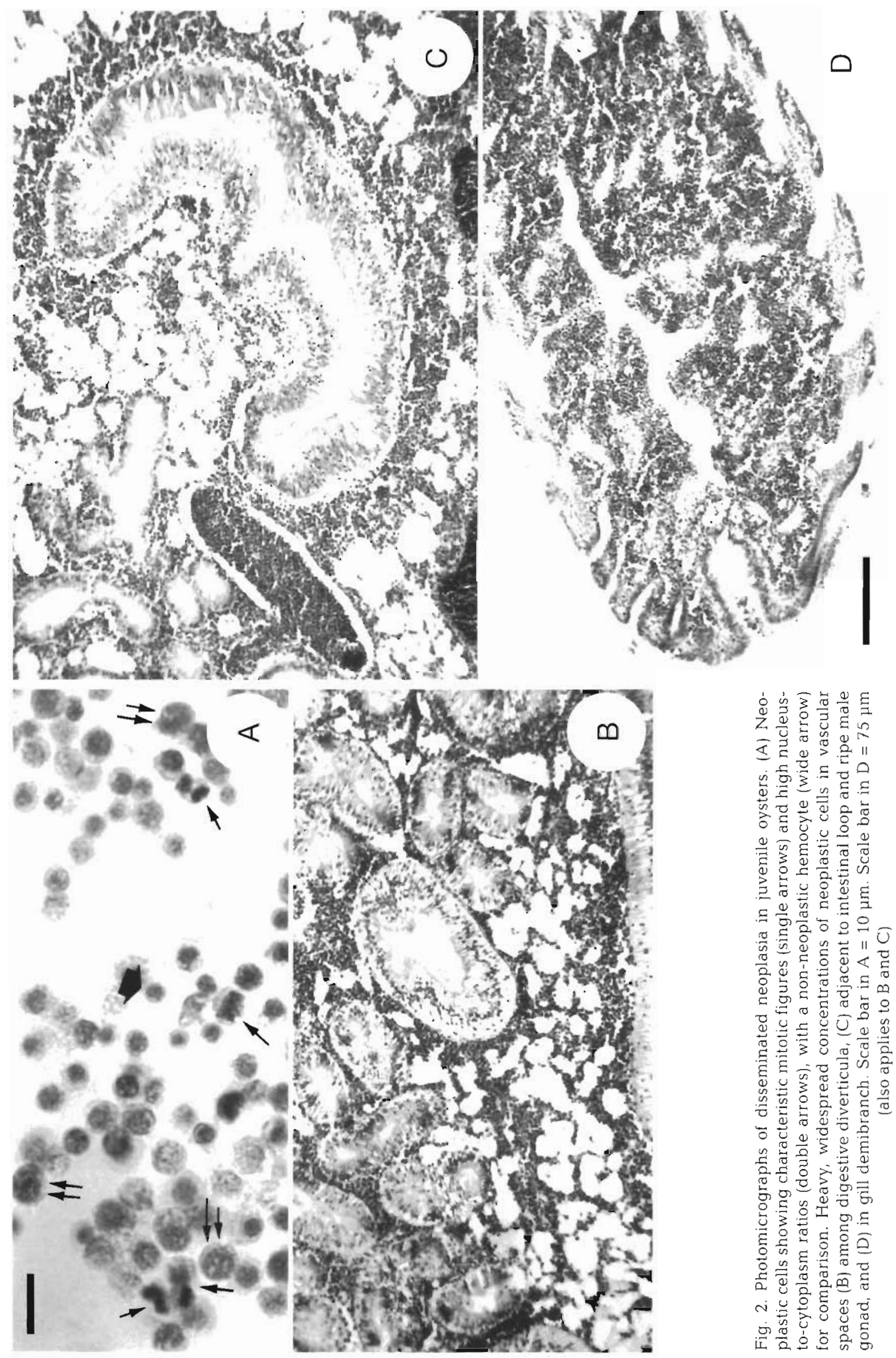




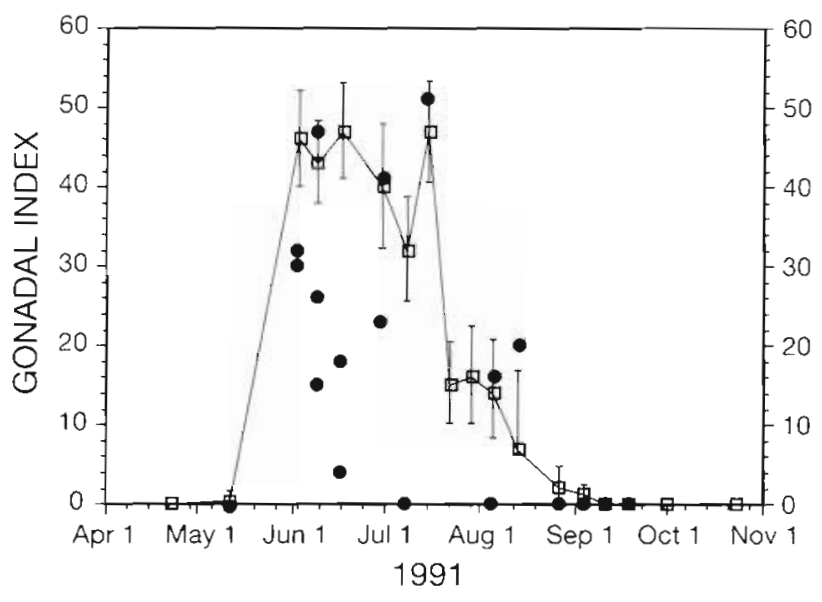

Fig. 3. Gonadal indices of non-neoplastic (ㅁ) and neoplastic (-) juvenile oysters in the 1990 year class collected from lower Delaware Bay intertidal flats in 1991. Indices for nonneoplastic oysters are given as the sample mean \pm 1 standard error; those for neoplastic oysters are shown as individual values. Total $\mathrm{N}$ (neoplastic and non-neoplastic oysters) for each sampling date $=19$ to 20

Why did this particular group of oysters experience such an uncommonly high incidence of neoplasia? The site is water approved for shellfish harvesting, indicating that chemical contaminants were not a factor. The only other reported epizootic of neoplasia in eastern oysters involved inbred stocks, suggesting a genetic basis for the condition (Frierman 1976). Although our finding was from a single year class that set at a single location, the oysters were derived from natural stocks throughout Delaware Bay. A more likely explanation than genetics for our finding lies in the fact that the 1990 spat fall was unusually heavy. Setting was far more intense than at any time since our juvenile oyster survey began in 1988. We collected oysters that had set on shells contained in mesh bags. The extreme crowding on the shells and within the bags undoubtedly posed a stress, perhaps aggravated by gametogenesis and the relatively high temperatures at this intertidal location, that could have provoked the development of neoplasia. Crowding would also have increased the probability of transmission, if a viral agent is involved (Oprandy et al. 1981) or if neoplastic cells shed from affected individuals become established in unaffected oysters (Farley 1987, Elston et al. 1988, Twomey \& Mulcahy 1988). Studies linking high population density and restricted water circulation with elevated mussel neoplasia both in the field and in laboratory experiments (EIston et al. 1992) support the hypothesis that the density of the oyster set in our study may have promoted the high neoplasia incidence.
Acknowledgements. This study was supported by grants no NA90AA-D-FM460 and NA26EL0382001 under the NOAA/ Oyster Disease Research Program. This is contribution no. 9623 from the Institute of Marine and Coastal Science at Rutgers and New Jersey Agricultural Experiment Station Publication No. D-32405-1-96, supported by state funds.

\section{LITERATURE CITED}

Barber BJ, Ford SE, Haskin HH (1988) Effects of the parasite MSX (Haplosporidium nelsoni) on oyster (Crassostrea virginica) energy metabolism. I. Condition index and relative fecundity. J Shellfish Res 7:25-31

Barber RD, Kanaley SA, Ford SE (1991) Evidence for regular sporulation by Haplosporidium nelsoni (MSX) (Ascetospora: Haplosporidiidae) in spat of the American oyster, Crassostrea virginica. J Protozool 38:305-306

Cosson-Mannevy MA, Wong CS. Cretney WJ (1984) Putative neoplastic disorders in mussels (Mytilus edulis) from southern Vancouver Island waters, British Columbia. J Invertebr Pathol 44:151-160

Couch JA (1969) An unusual lesion in the mantle of the American oyster, Crassostrea virginica. In: Dawe CJ, Harshbarger JC (eds) National Cancer Institute Monograph, Vol. 31. Washington, DC, p 557-562

Couch JA (1985) Prospective study of infectious and noninfectious diseases in oysters and fishes in three Gulf of Mexico estuaries. Dis Aquat Org 1:59-82

Couch JA, Winstead JT (1977) Concurrent neoplastic and protistan disorders in the American oyster (Crassostrea virginica). Haliotis 8:249-253

Elston RA, Kent JL, Drum AS (1988) Transmission of hemic neoplasia in the bay mussel, Mytilus edulis, using whole cells and cell homogenate. Dev Comp Immunol 12:719-727

Elston RA, Moore JD, Brooks K (1992) Disseminated neoplasia of bivalve molluscs. Rev Aquat Sci 6:405-466

Farley CA (1969) Probable neoplastic disease of the hematopoietic system in oysters, Crassostrea virginica and Crassostrea gigas. In: Dawe CJ, Harshbarger JC (eds) National Cancer Institute Monograph, Vol. 31. Washington, DC. p 541-555

Farley CA (1987) Selected aspects of neoplastic progression in mollusks. In: Kaiser $\mathrm{HE}$ (ed) Progressive stages of malignant growth/development, Vol. II, Part 4. Martinus Ni.jhofe, New York, p 1-14

Ford SE (1986) Effect of repeated hemolymph sampling on growth, mortality, hemolymph protein, and parasitism of oysters, Crassostrea virginica. Comp Blochem Physiol $85 \mathrm{~A}: 465-470$

Frierman EM (1976) Occurrence of hematopoietıc neoplasms in Virginia oysters (Crassostrea virginica). Mar Fish Rev $38: 34-36$

Gabbott PA (1975) Storage cycles in marine bivalve molluscs: a hypothesis concerning the relationship between glycogen metabolism and gametogenesis. In: Barnes $\mathrm{H}$ (ed) Proc 9th Eur Mar Biol Symp. Aberdeen University Press, Aberdeen, p 191-211

Hesselman DM. Blake NJ, Peters EC (1988) Gonadal neoplasms in hard shell clams Mercenaria spp., from the Indian River, Florida: occurrence, prevalence, and histopathology. J Invertebr Pathol 52:436-4.46

Newman MS (1972) An oyster neoplasm of apparent mesenchymal origin. J Nat Cancer Inst 48:237-243

Oprandy JJ, Chang PW, Pronovost AD, Cooper KR, Brown RS, Yates VJ (1981) Isolation of a viral agent causing hemo- 
poretic neoplasia in the soft-shell clam, Mya arenaria. J Invertebr Patho] 42:196-206

Peters E (1988) Recent investigations on the disseminated sarcomas of marine bivalve molluscs. In: Fisher WS (ed) Disease processes in marine bivalve molluscs, Vol. 18. American Fisherjes Society, Bethesda, MD, p 74-92

Responsible Subject Editor: A. K. Sparks, Seattle, Washington, USA
Rasmussen LPD (1986) Occurrence, prevalence and seasonality of neoplasia in the marine mussel Mytilus edulis from three sites in Denmark. Mar Biol 92:59-64

Twomey E, Mulcahy MF (1988) Transmission of a sarcoma in the cockle Cerastoderma edule (Bivalvia: Mollusca) using cell transplants. Dev Comp Immunol 12:195-200

Manuscript first received: March 15, 1996

Revised version accepted: August 21, 1996 